\title{
AFRICAN DEVELOPMENT BANK
}

Established in 1964 to promote economic and social development in Africa.

Regional Members. (53) Algeria, Angola, Benin, Botswana, Burkina Faso, Burundi, Cameroon, Cape Verde, Central African Republic, Chad, Comoros, Congo (Dem. Rep. of), Congo (Rep. of), Côte d'Ivoire, Djibouti, Egypt, Equatorial Guinea, Eritrea, Ethiopia, Gabon, The Gambia, Ghana, Guinea, Guinea-Bissau, Kenya, Lesotho, Liberia, Libya, Madagascar, Malaŵi, Mali, Mauritania, Mauritius, Morocco, Mozambique, Namibia, Niger, Nigeria, Rwanda, São Tomé e Príncipe, Senegal, Seychelles, Sierra Leone, Somalia, South Africa (Rep. of), Sudan, Swaziland, Tanzania, Togo, Tunisia, Uganda, Zambia, Zimbabwe.

Non-regional Members. (24) Argentina, Austria, Belgium, Brazil, Canada, China, Denmark, Finland, France, Germany, India, Italy, Japan, South Korea, Kuwait, Netherlands, Norway, Portugal, Saudi Arabia, Spain, Sweden, Switzerland, UK, USA.

Within the ADB Group is the African Development Fund, established in 1972, which provides development finance on concessional terms to low-income Regional Member Countries which are unable to borrow on the non-concessional terms of the African Development Bank. Membership of the Fund is made up of 25 nonAfrican State Participants, the African Development Bank and the Nigerian Trust Fund.

Official languages: English, French.

Headquarters: 01 BP 1387, Abidjan 01, Côte d'Ivoire.

Website: http://www.afdb.org

e-mail: afdb@afdb.org

President: Omar Kabbaj (Morocco).

\section{AFRICAN EXPORT-IMPORT BANK (AFREXIMBANK)}

Established in 1987 under the auspices of the African Development Bank to facilitate, promote and expand intra-African and extra-African trade. Membership is made up of three categories of shareholders: Class 'A' Shareholders consisting of African governments, African central banks and sub-regional and regional financial institutions and economic organizations; Class 'B' Shareholders consisting of African public and private financial institutions; and Class ' $\mathrm{C}$ ' Shareholders consisting of international financial institutions, economic organizations and nonAfrican states, banks, financial institutions and public and private investors.

Official languages: English, French, Arabic, Portuguese.

Headquarters: World Trade Center, 1191 Corniche El-Nil, Cairo 11221, Egypt.

Website: $\mathrm{http} / / \mathrm{www}$.afreximbank.com

President and Chairman to the Board: Christopher C. Edordu.

\section{AFRICAN UNION (AU)}

History. The Fourth Extraordinary Session of the Assembly of the Heads of State and Government of the Organization of African Unity (OAU) held in Sirté, Libya on 9 Sept. 1999 decided to establish an African Union. At Lomé, Togo on 11 July 2000 the OAU Assembly of the Heads of State and Government adopted the Constitutive Act of the African Union, which was later ratified by the required twothirds of the member states of the Organization of African Unity (OAU); it came into force on 26 May 2001. The Lusaka Summit, in July 2001, gave a mandate to 